\title{
Socio-Psychological Factors of User Trust in Information in Electronic Mass Communication
}

\author{
MARIIA SHPAK ${ }^{1}$, ANTONINA KICHUK ${ }^{2}$, OLEKSII SYTNYK ${ }^{3}$, NATALIIA ISHCHUK ${ }^{4}$, \\ DANYLO FILONENKO ${ }^{5}$, OLENA HROZNA ${ }^{6}$ \\ ${ }^{1}$ Department of Developmental Psychology and Counseling, TERNOPIL VOLODYMYR HNATIUK NATIONAL \\ PEDAGOGICAL UNIVERSITY, UKRAINE. \\ ${ }^{2}$ Department of General and Practical Psychology, IZMAIL STATE UNIVERSITY OF HUMANITIES, UKRAINE. \\ E-mail: kichuk20220@gmail.com \\ 3,4,5.6 Department of Multimedia Technologies and Mediadesign, TARAS SHEVCHENKO NATIONAL UNIVERSITY \\ OF KYIV, UKRAINE.
}

\begin{abstract}
The relevance of the topic of trust is because, in the modern world, the media have a huge impact on public consciousness. Based on what people have heard in the news, read on the Internet, a definite opinion is formed on this or that issue. That is why a person is simultaneously exposed to different sides of such media like television, newspapers, broadcast media. It is not easy to navigate and understand the huge flow of information since a person does not always have the opportunity to check the material's reliability. Most often, after receiving information, a person perceives it as the only correct one, which contributes to the formation of false ideas that have nothing to do with the truth.

The constant increase in the volume of information and its sources (in particular, the Internet) raises the question of trust in information. The focus of attention is the very existence of this phenomenon, its relationship with various factors, the relationship between trust in information and broader concepts.

During the experiment, the authors revealed that the properties of the information that determine its reliability have a specific hierarchy of significance depending on the type of information. The more important the information is for the user, the more significant is its reliability for trusting it. Once the information's importance decreases, its credibility is determined by several properties of the information. The authors determined which sources users trust most and least and made a user's portrait with the most developed critical thinking.

The results obtained can be used to develop a program to increase audience confidence in online media and to develop a program to form a more critical audience attitude to information. The obtained results on trust in information and its socio-psychological factors are based on the key methodological principles of psychological science and supplement the existing knowledge on the issues of trust and distrust concerning information in electronic mass communication.
\end{abstract}

Keywords: electronic mass communication, information, Internet, user trust

JEL Classification: L82, L80 


\section{Introduction.}

The current time is the age of information that regulates the relationship of people as a resource. Researchers assign the primary role in disseminating information to the Internet [1], which has changed people's ideas about the communication process in less than thirty years. The traditional mass media also underwent a transformation, becoming less elite and less accessible to ordinary users under the influence of the Internet, which led to the emergence of "citizen journalism".

The constant increase in the volume of information and its sources (in particular, the Internet) raises the question of trust in information. The focus of attention is the very existence of this phenomenon, its relationship with various factors, the relationship between trust in information and broader concepts. In particular, this study involves the study of the foundations of trust in information and its socio-psychological factors in the process of online mass communication, which is an attempt to consider the socio-psychological nature of trust in information and its source on the example of the Internet.

\section{Theoretical foundations of the research.}

\subsection{Literature review.}

The problem of attitude to information has been considered science since the sixties of the last century. However, at present, the scientific community has not developed a unified understanding of information and approaches to its study. In social psychology, information was not studied independently but was included in a broader range of issues: the unity of communication and cognition [2]; meanings, which are exchanged by the participants of communication [3]; media psychology [4-5]; psychology of rumours [6]; engineering psychology and ergonomics [7]; psychology of advertising [8]; theory of social representations [9].

\subsection{Theoretical basis.}

Electronic media is an electronic resource created to fulfil the functions of mass media, which enjoys authority among a certain audience.

It should be noted that many scientists classify not only websites as electronic media but also television and radio broadcasting. According to the Law of Ukraine in television and radio broadcasting:

audiovisual (electronic) mass media - an organization that provides audiovisual information for mass reception by consumers, transmitted in the form of electrical signals and received using household electronic devices [10].

However, to outline the circle of research, we will mean exactly the content posted on the Internet (website, social networks, blog, etc.) by electronic mass media.

The first electronic media had only text content since Internet technologies did not yet have the resources to transfer images, audio and video files. Only in 2000 appeared online publications in which images accompanied the text. Illustrations revolutionized online content because they grabbed the attention and dramatically increased the opportunities for advertisers. In 2005-2006, with the advent of the YouTube network, it became possible to supplement electronic text publications and video files, which helped improve the message's quality.

Electronic media have many advantages over print media. First of all, the frequency or regularity of content updates can be carried out autonomously in each section or heading at different intervals. For example, information may be updated as information becomes available, rather than depending on the edition of the publication. Therefore, the news appears almost in real-time.

The fundamental difference between electronic media and print media is the interactivity of online publications, in which the user has the opportunity to read the text using hyperlinks, participate in the creation of texts, etc. 
Due to the fact that any news on the Internet can be easily posted, the problem of the low quality of publications on the Internet has been sharply identified. First of all, the media operating in a competitive environment must comply with the following requirements when disclosing information: efficiency, accuracy in conveying details, and literacy. One of the important factors in the competitiveness of any media should be considered the level of professionalism of the publication, that is, the presence of professional journalists on the staff. The reputation of the company and the sources of information have become the most important factors that ensure the high popularity of the electronic edition among the readers. Given the communicative features of the environment, the style of presenting information in online media is somewhat different. The specific features of the "network text" are determined by the functioning of the network as a media environment and the peculiarities of perceiving information from the monitor screen. In addition, the behaviour of the electronic media reader differs significantly from the audience of the traditional press.

Research shows that most web visitors prefer quick familiarization with text. The reason for this is:

First, the hypertext nature of the environment and vast amounts of information, from which it is necessary to choose only what the user really needs. The web is an interactive environment in which visitors navigate between different blocks of information using hyperlinks.

Secondly, these are the problems of visual perception of information in Internet publications. It is known that reading text from a monitor screen is about $25 \%$ slower than in print media. Therefore, the overwhelming majority of the audience avoids large-volume texts. Consequently, the most receptive will be a short informational article that reflects current events.

There are many benefits of electronic media (Figure 1).

The Internet is gradually becoming one of the main information sources from which people receive information of interest to them, including news. Against this background, the emergence and intensive development of social media was a logical continuation of society's comprehensive processes of informatization. Today, one of the most popular sources of news on the Internet is social networks, blogs and forums: in the daily audience, two-thirds of the respondents have recently used them.

Many experts expected that such a scale and intensity of communications, an abundance of information would create the preconditions for openness, public control, civil and political participation, and the development of civil society. In reality, the result was somewhat different. Selfsufficient network communities have formed, rather distrustful and aggressive towards others. There is a kind of hypertrophied excitement on line, which does not lead to cooperation and partnership of off-line social forces.

One of the main functions of the mass media is the transmission of information. At the same time, trust in information is a significant factor in any communication. However, trust in information does not exist by itself but is in a certain relationship with the "closest" trust, that is, trust in its source [11].

In psychology, the phenomenon of trust is figuratively qualified as a "category of increased complexity", "a subtle psychological phenomenon", which indicates, first of all, the extreme laboriousness of its research due to its high dynamism, multifactorial and multidimensionality.

In our study, trust in information within the Internet space was considered in conjunction with several socio-psychological factors. 
Figure 1. Benefits of Electronic Media

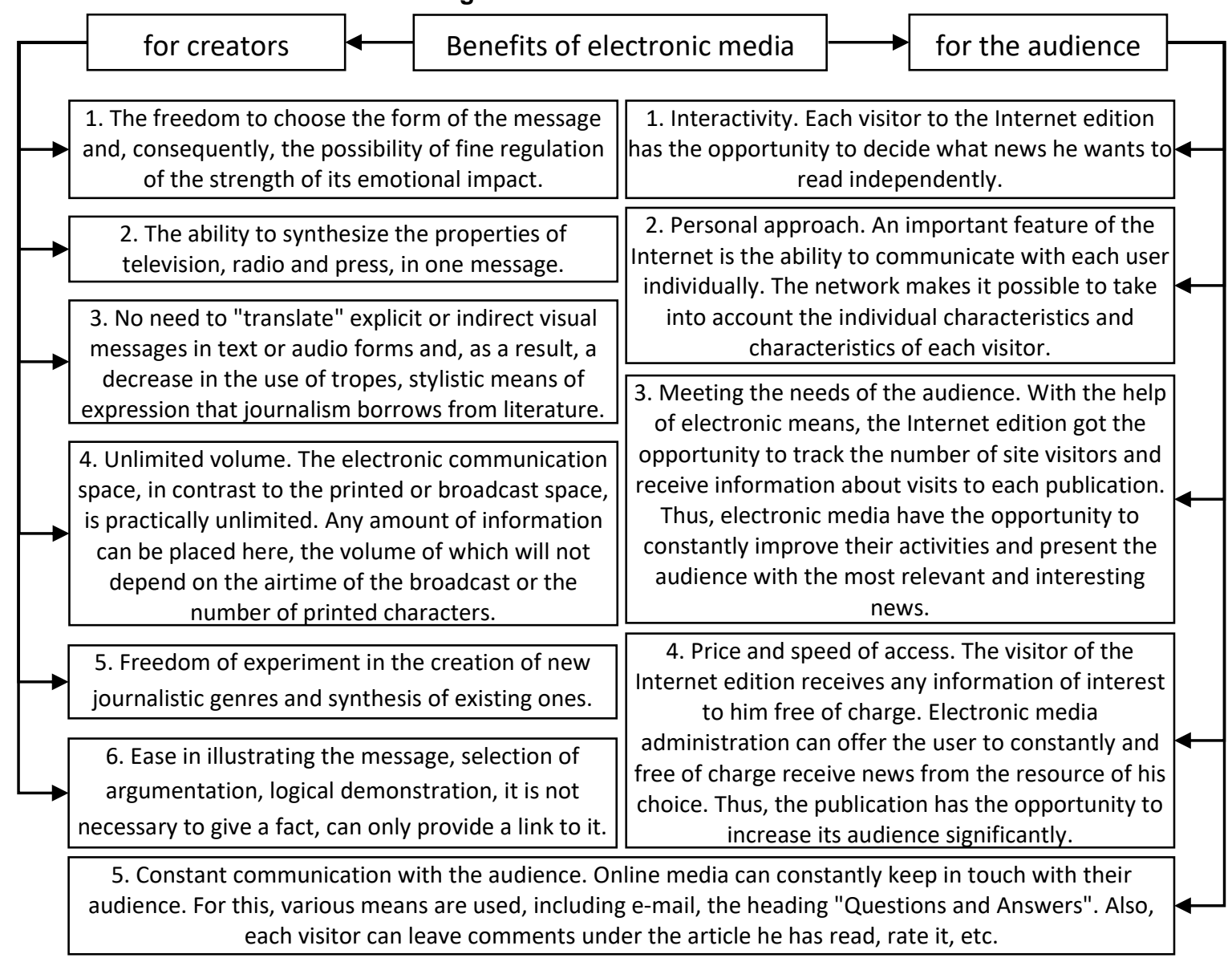

\section{Experiment program and its implementation.}

In accordance with this goal, our research instruments included the author's questionnaire to measure the relationship of trust in information.

Considering the variety of topics in electronic mass media, we have identified six types of information used by the audience to varying degrees (Table 1).

In the course of developing the methodological toolkit, we carried out a number of pilot studies in the period 2017-2019. with a total sample size of 386 people by polling (filling out a questionnaire) via the Internet - social networks (Facebook, Instagram), posting a link to the survey in various professional communities, in the form of comments under various entertaining and professional videos on youtube and others, and 84 people (in most people over 50 years old, who, as a rule, use the Internet less often, social networks, etc.).

In anticipation of the main experiment, the authors found that trust in information has a strong relationship with distrust of other people, trust in oneself in the ability to predict the actions of other people, and distrust of the world, which other people assess negatively. At the same time, this relationship is preserved with all the types of information we have selected. Trust in electronic media is strongly correlated with distrust in the world and in other people and less correlated with trust in the world, in other people and in oneself. These relationships do not depend on the specific type of information. As a result of this analysis, five types were identified based on trust/distrust in the world, in other people and in oneself (Table 2). 
Table 1. Type of information

\begin{tabular}{|c|l|}
\hline $\begin{array}{c}\text { Type of information } \\
\text { Professional, } \\
\text { practically useful }\end{array}$ & $\begin{array}{l}\text { Clarification } \\
\text { the content that is directly related to the work of the } \\
\text { recipient and which he can directly use in his daily affairs and } \\
\text { work. }\end{array}$ \\
\hline $\begin{array}{c}\text { Professional, } \\
\text { almost useless }\end{array}$ & $\begin{array}{l}\text { the content that is directly related to the recipient's work but } \\
\text { which he cannot directly use in his daily affairs and work. }\end{array}$ \\
\hline $\begin{array}{c}\text { Entertaining, } \\
\text { practically useful }\end{array}$ & $\begin{array}{l}\text { the content with the help of which the recipient can have fun, } \\
\text { distract himself from his daily problems and worries, and } \\
\text { which he can directly use in his daily affairs and work. }\end{array}$ \\
\hline $\begin{array}{c}\text { Entertaining, } \\
\text { almost useless }\end{array}$ & $\begin{array}{l}\text { the content with the help of which the recipient can have fun, } \\
\text { distract himself from his daily problems and worries, but } \\
\text { which he cannot directly use in his daily affairs and work. }\end{array}$ \\
\hline $\begin{array}{c}\text { Informational noise, } \\
\text { practically useful }\end{array}$ & $\begin{array}{l}\text { the content that the recipient did not specifically look for, it } \\
\text { appeared by accident (sent by friends, appeared as an } \\
\text { advertising message) and which he can directly use in his daily } \\
\text { affairs and work. }\end{array}$ \\
\hline $\begin{array}{l}\text { Information noise, } \\
\text { practically useless }\end{array}$ & $\begin{array}{l}\text { the content that the recipient did not specifically look for, it } \\
\text { appeared by accident (sent by friends, appeared as an } \\
\text { advertising message) and which he cannot directly use in his } \\
\text { daily affairs, work, moreover, is distracting and/or an } \\
\text { annoying factor. }\end{array}$ \\
\hline
\end{tabular}

Table 2. Types of trust/distrust in information depending on personal socio-psychological factors

\begin{tabular}{|c|l|}
\hline Trust / distrust types & \multicolumn{1}{|c|}{ Characteristics } \\
\hline $\begin{array}{c}\text { The first type (37.1\%) "High } \\
\text { confidence in oneself and low } \\
\text { distrust in the world and in } \\
\text { other people" }\end{array}$ & $\begin{array}{l}\text { Have moderate information requirements. An } \\
\text { orientation towards one's own opinion is } \\
\text { characteristic in almost all life situations. They } \\
\text { practically do not use electronic media (46.81\%) or } \\
\text { use online media specialized in various topics (21.5\%). }\end{array}$ \\
\hline $\begin{array}{c}\text { The second type (12.5\%) } \\
\text { "Ambivalent basic trust / } \\
\text { distrust" }\end{array}$ & $\begin{array}{l}\text { Have moderate information requirements. Ability to } \\
\text { show social flexibility - understanding situations } \\
\text { where it is necessary to show trust or distrust. Most of } \\
\text { all, do not use social networks (63.3\%) and use only } \\
\text { authoritative electronic media (22.1\%). }\end{array}$ \\
$\begin{array}{c}\text { The third type (18.95\%) "High } \\
\text { self-confidence and distrust of } \\
\text { other people and moderate } \\
\text { distrust of the world" }\end{array}$ & $\begin{array}{l}\text { Opposing yourself to other people: your own opinion } \\
\text { is the only correct one, and the people around you are } \\
\text { unequal. Most of all use electronic media specialized } \\
\text { in various topics (31.4\%) or do not use Internet } \\
\text { content at all (48.7\%). They make the greatest } \\
\text { demands on the information. }\end{array}$ \\
\hline $\begin{array}{c}\text { The fourth type (12.4\%) "High } \\
\text { self-confidence and ambivalent } \\
\text { trust/distrust in the world and in } \\
\text { other people" }\end{array}$ & $\begin{array}{l}\text { Have moderate information requirements. } \\
\text { Manifesting trust or distrust to others in order to } \\
\text { preserve your inner peace - "trust but verify." Most of } \\
\text { all use electronic diaries, social networks (42.4\%), or } \\
\text { Internet resources specialized on various topics } \\
\text { (32.8\%). }\end{array}$ \\
\hline
\end{tabular}




\begin{tabular}{|c|l|}
\hline $\begin{array}{c}\text { Fifth type (10.3\%) "High } \\
\text { confidence in oneself, moderate } \\
\text { trust in other people and low } \\
\text { distrust in the world" }\end{array}$ & $\begin{array}{l}\text { Orientation to the world around us with faith in its } \\
\text { justice and regularity of events. They use electronic } \\
\text { media specialized in various topics (46.5\%). Have the } \\
\text { least information requirements. }\end{array}$ \\
\hline $\begin{array}{c}\text { The sixth type (7.0\%) "Low self- } \\
\text { confidence, high trust in other } \\
\text { people and moderate distrust of } \\
\text { the world" }\end{array}$ & $\begin{array}{l}\text { They have low requirements for information; most of } \\
\text { all, they trust influencers. Rarely can they form their } \\
\text { point of view. Most of all use social networks (74.5\%) } \\
\text { and personal electronic media (45.8\%). }\end{array}$ \\
\hline
\end{tabular}

The results demonstrate that the basic mistrust of the individual performs a protective function, and the prevalence of basic mistrust makes the individual demanding and selective about information in the electronic media and when deciding whether to trust it. Low distrust, which creates in the individual a sense of the justice of the world and, possibly, utopian consciousness, leads to low selectivity and relatively easy emergence of trust in the information received.

\section{Experiment results.}

A total of 470 people participated in the study, of which $68 \%$ were girls, $32 \%$ were boys. The age of the respondents in the entire sample is from 18 to 68 years old (the main group - more than $80 \%-$ from 18 to 48 years old).

According to the research results, the respondents were divided into four groups: a) Groupe 1: those who do not use electronic media - $18.6 \%$; b) Groupe 2: those who use electronic media, but are unable to indicate their specifics, do not use social networks - 12.3\%; c) Groupe 3: those who use Internet magazines specialized on various topics (sites on management, economics, politics, sports, art) $-20.8 \%$; d) Groupe 4 : using information Internet portals, blogs, social networks, where they read news, articles on various topics $-48.3 \%$. A group of respondents who do not use

It should be noted that under "uses social networks", - it means that they are used not only for communication but also for informational content. Almost $86 \%$ of respondents who use the Internet use social media.

Descriptive analysis of the results of assessing trust in information in all groups of respondents allows us to trace the hierarchy of information properties in terms of their significance for trust in it (Table 3).

As you can see from the table. 3 , the properties of the information that determine its reliability have different significance depending on the type of information. For confidence in professional, practically useful information, that is, information that is of high importance to the user, the most important are reliability and objectivity. At the same time, completeness, accuracy and relevance are important for trust in entertaining, practically useless information, that is, information that is of less significance to the user.

Thus, the more important the information is for the user, the more significant is its reliability for trusting it. Once the information's importance decreases, its credibility is determined by several properties of the information.

Additional research findings are also worth noting.

According to the research results, Top-5 sources whose information is trusted:

1. electronic versions of well-known, respected newspapers;

2. official information of state bodies (website, official page in social networks)

3. Internet version of the leading national channels;

4. personal blog/channel of a well-known independent journalist;

5. content of the site where the recipient's mail is located 
Table 3. Socio-psychological factors of trust in information in electronic mass communication

\begin{tabular}{|c|c|c|c|c|c|c|c|c|c|}
\hline \multirow{2}{*}{$\begin{array}{c}\text { Information } \\
\text { properties }\end{array}$} & \multicolumn{2}{|c|}{ Groupe 1} & \multicolumn{2}{|c|}{ Groupe 2} & \multicolumn{2}{|c|}{ Groupe 3} & \multicolumn{2}{|c|}{ Groupe 4} & \multirow[b]{2}{*}{ Range } \\
\hline & $\begin{array}{c}\text { Average } \\
\text { value }\end{array}$ & $\begin{array}{l}\text { Standard } \\
\text { deviation }\end{array}$ & $\begin{array}{c}\text { Average } \\
\text { value }\end{array}$ & $\begin{array}{l}\text { Standard } \\
\text { deviation }\end{array}$ & $\begin{array}{c}\text { Average } \\
\text { value }\end{array}$ & $\begin{array}{l}\text { Standard } \\
\text { deviation }\end{array}$ & $\begin{array}{c}\text { Average } \\
\text { value }\end{array}$ & $\begin{array}{l}\text { Standard } \\
\text { deviation }\end{array}$ & \\
\hline \multicolumn{10}{|c|}{ Professional, practically useful } \\
\hline Objectivity & 5,49 & 1,58 & 5,21 & 1,54 & 5,28 & 1,62 & 5,47 & 1,39 & 0,28 \\
\hline Credibility & 5,55 & 1,57 & 5,54 & 1,54 & 5,48 & 1,66 & 5,32 & 1,63 & 0,23 \\
\hline Completeness & 5,16 & 1,54 & 5,21 & 1,52 & 5,32 & 1,57 & 4,89 & 1,11 & 0,43 \\
\hline Accuracy & 5,47 & 1,56 & 5,08 & 1,52 & 5,19 & 1,55 & 4,8 & 1,28 & 0,67 \\
\hline Relevance & 5,12 & 1,55 & 5,13 & 1,52 & 5,07 & 1,49 & 4,82 & 1,25 & 0,31 \\
\hline \multicolumn{10}{|c|}{ Professional, almost useless } \\
\hline Objectivity & 4,16 & 1,25 & 4,31 & 1,28 & 4,29 & 1,27 & 4,27 & 1,06 & 0,15 \\
\hline Credibility & 4,12 & 1,26 & 4,25 & 1,33 & 4,14 & 1,31 & 4,13 & 1,26 & 0,12 \\
\hline Completeness & 3,99 & 1,16 & 4,06 & 1,26 & 4,13 & 1,24 & 3,55 & 0,91 & 0,58 \\
\hline Accuracy & 4,08 & 1,23 & 4,26 & 1,25 & 4,04 & 1,25 & 3,76 & 1,05 & 0,50 \\
\hline Relevance & 3,51 & 1,13 & 4,21 & 1,26 & 4,2 & 1,19 & 3,87 & 1,00 & 0,69 \\
\hline \multicolumn{10}{|c|}{ Entertaining, practically useful } \\
\hline Objectivity & 4,28 & 1,30 & 4,52 & 1,38 & 4,19 & 1,29 & 4,18 & 1,13 & 0,34 \\
\hline Credibility & 4,25 & 1,30 & 4,58 & 1,42 & 4,15 & 1,33 & 4,39 & 1,32 & 0,43 \\
\hline Completeness & 4,39 & 1,20 & 4,67 & 1,34 & 4,28 & 1,25 & 4,37 & 0,96 & 0,39 \\
\hline Accuracy & 4,40 & 1,27 & 4,63 & 1,34 & 4,23 & 1,26 & 4,23 & 1,12 & 0,40 \\
\hline Relevance & 4,01 & 1,19 & 4,81 & 1,33 & 4,32 & 1,20 & 4,38 & 1,06 & 0,80 \\
\hline \multicolumn{10}{|c|}{ Entertaining, almost useless } \\
\hline Objectivity & 3,16 & 1,21 & 3,43 & 1,22 & 3,40 & 1,21 & 3,03 & 1,08 & 0,40 \\
\hline Credibility & 3,23 & 1,22 & 3,54 & 1,28 & 3,35 & 1,24 & 2,79 & 1,23 & 0,75 \\
\hline Completeness & 3,30 & 1,11 & 3,59 & 1,18 & 3,41 & 1,17 & 2,73 & 0,85 & 0,86 \\
\hline Accuracy & 3,16 & 1,19 & 3,56 & 1,19 & 3,44 & 1,16 & 2,97 & 0,97 & 0,59 \\
\hline Relevance & 3,07 & 1,03 & 3,24 & 1,19 & 3,23 & 1,11 & 3,18 & 0,97 & 0,17 \\
\hline \multicolumn{10}{|c|}{ Informational noise, practically useful } \\
\hline Objectivity & 2,04 & 1,37 & 1,92 & 1,43 & 1,84 & 1,40 & 1,87 & 1,27 & 0,20 \\
\hline Credibility & 2,12 & 1,39 & 1,99 & 1,50 & 1,90 & 1,44 & 2,05 & 1,38 & 0,22 \\
\hline Completeness & 2,13 & 1,28 & 2,00 & 1,40 & 1,94 & 1,39 & 2,26 & 1,09 & 0,32 \\
\hline Accuracy & 2,05 & 1,36 & 1,93 & 1,40 & 1,87 & 1,35 & 1,89 & 1,12 & 0,18 \\
\hline Relevance & 2,16 & 1,17 & 2,03 & 1,41 & 2,05 & 1,34 & 2,15 & 1,16 & 0,13 \\
\hline \multicolumn{10}{|c|}{ Information noise, practically useless } \\
\hline Objectivity & 1,06 & 1,67 & 1,00 & 1,72 & 1,01 & 1,68 & 2,14 & 1,45 & 1,14 \\
\hline Credibility & 1,01 & 1,68 & 0,95 & 1,78 & 0,92 & 1,70 & 0,93 & 1,42 & 0,09 \\
\hline Completeness & 1,18 & 1,60 & 1,11 & 1,70 & 1,12 & 1,68 & 2,28 & 1,26 & 1,17 \\
\hline Accuracy & 1,16 & 1,67 & 1,09 & 1,70 & 1,06 & 1,64 & 1,65 & 1,26 & 0,59 \\
\hline Relevance & 1,21 & 1,49 & 1,14 & 1,71 & 1,15 & 1,63 & 1,65 & 1,29 & 0,51 \\
\hline
\end{tabular}


Top 3 sources, the information of which is not trusted:

1. news channels owned by politicians;

2. regional electronic media, usually reprinting the content of others;

3. hype influencers

Top 5 sources whose information is trusted by information sources:

1. information from an influencer (by personal choice);

2. information sent by a narrow circle of friends/relatives;

3. personal subscription to certain channels;

4. personal subscription to certain groups;

5. information sent by friends.

Also, the authors were able to suggest a portrait of a most critical person of information, e its properties, sources, i.e. has developed critical thinking (Fig. 4).

Figure 4. Development of critical thinking among respondents

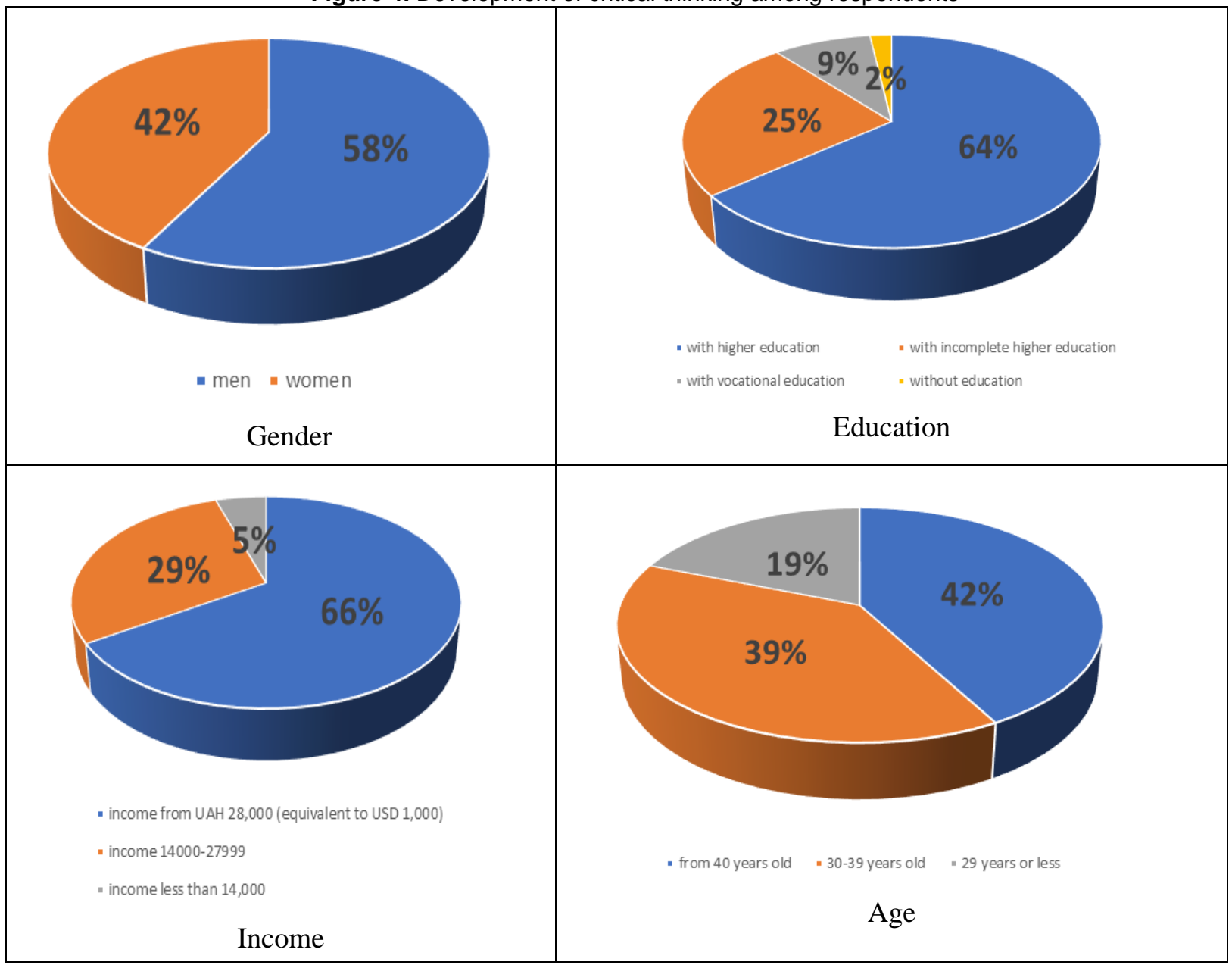

Thus, the study showed that the older a person is, the better his education and higher income, the more critically he evaluates the information received, incl. from electronic media.

\section{Conclusions.}

The principles of the classical theory of information and psychosomatics, when explaining the nature of information, focus on its sociality, dependence on social experience, practice and human interaction, which makes it the subject of social psychology. Intrust in information, the most significant component is "reliability" since the rest of the components and their substitutes - 
"predictability", "unity", "affection", etc. - are largely levelled by the very nature of the information. The "reliability" component in trusting information is based on the following properties: objectivity, reliability, completeness, accuracy and relevance.

The properties of the information that determine its reliability have a specific hierarchy of significance depending on the type of information. The more important the information is for the user, the more significant is its reliability for trusting it. Once the information's importance decreases, its credibility is determined by several properties of the information. Most users trust information posted in electronic versions of well-known, respected newspapers and on the official websites of state bodies; the least - news channels owned by politicians. Also, the relationship depends on the source from which the link to the information itself is received. The most trusted information is provided by influencers, whom everyone chooses according to personal preferences. Also, the older a person is, the better his education and higher income, the more critically he evaluates the information received, incl. from electronic media.

\section{References}

1. Koval, V., Kremenetskaya, Y., Markov, S. (2019). Promising green telecommunications based on hybrid network architecture. 2019 International Conference on Information and Telecommunication Technologies and Radio Electronics, UkrMiCo 2019 - Proceedings, Article number 9165525.

2. Xiong, W. et al. (2020). Covert Communication With Cognitive Jammer. IEEE Wireless Communication Letters, (99):1-1 DOI: 10.1109/LWC.2020.3003472

3. Guamba, J. (2021). Management of conservation areas with participation of communities in Mozambique. International Journal of Research, 9(1), 189-201. DOI: 10.29121/granthaalayah.v9.i1.2021.2990

4. Altheide, D. (2020). Media Logic and Media Psychology. DOI: 10.1002/9781119011071.iemp0227

5. Rutledge, P. (2020). Positive Media Psychology. DOI: 10.1002/9781119011071.iemp0281

6. Takenaka, I. (2008). Information transferred from person to person - Interpersonal psychology of rumor. Journal of the Japan Research Association for Textile End-Uses, 49(7), 39-48.

7. Semionov, I. (2018). A.N. Leontiev contribution in the development of psychology of thinking, engineering psychology and ergonomics. University Psychology Bulletin, 2018(3), 3-20. DOI: 10.11621/vsp.2018.03.03

8. Fennis, B., Stroebe, W. (2020). The Psychology of Advertising. DOI: 10.4324/9780429326981

9. Harré, R., Moghaddam, A. (2015). Positioning theory and social representations. DOI: 10.1017/СВ09781107323650.019

10.The Law of Ukraine in television and radio broadcasting. https://zakon.rada.gov.ua/cgibin/laws/main.cgi?nreg=3759-12\&p=1239267667879110\#Text

11.Semigina, T., Vysotska, Z., Kyianytsia, I., Kotlova, L., Shostak, I., Kichuk, A. (2020). Psychoemotional state of students: Research and regulation. Estudios de Economia Aplicada, 38(4) 